\title{
SHORT COMMUNICATIONS КРАТКИЕ СООБЩЕНИЯ FAUNA OF THE FAMILY DOLICHOPODIDAE (DIPTERA) OF THE ASTRAKHAN STATE NATURE BIOSPHERE RESERVE (RUSSIA)
}

\author{
Oleg P. Negrobov ${ }^{1}$, Olga O. Maslova ${ }^{2}$, Olga V. Selivanova ${ }^{1}$ \\ ${ }^{1}$ Voronezh State University, Russia \\ e-mail:negrobov@list.ru \\ ${ }^{2}$ Voronezh State Pedagogical University, Russia \\ e-mail:oom777@yandex.ru
}

Received: 17.06 .2018

\begin{abstract}
The paper presents a critical review of the Dolichopodidae family in the Astrakhan State Nature Biosphere Reserve (Russia). In total, 23 species from the Dolichopodidae family were indicated for this Protected Area. Four of these species have been recorded for the first time for both Europe and Russia: Asyndetus albipalpus, Asyndetus chaetifemoratus, Chrysotus dorli, Hercostomus rubroviridissimus. In addition, Dolichopus jaxarticus and Sciapus subvicinus are new species for Russia. Twenty species (Asyndetus albipalpus, Asyndetus chaetifemoratus, Asyndetus latifrons, Campsicnemus filipes, Campsicnemus simplicissimus, Chrysotus cilipes, Chrysotus dorli, Dolichopus calinotus, Dolichopus cilifemoratus, Dolichopus latilimbatus, Dolichopus jaxarticus, Hercostomus convergens, Hercostomus rubroviridissimus, Medetera diadema, Medetera plumbella, Nematoproctus longifilus, Poecilobothrus bigoti, Rhaphium penicillatum, Sciapus longulus, Sciapus subvicinus) are firstly recorded for the Astrakhan region. To date, 34 Dolichopodidae species are known in the Astrakhan region. However, further studies of the Dolichopodidae fauna in Protected Areas are needed for a more comprehensive knowledge on this Diptera family in Russia and in Eurasia as a whole.
\end{abstract}

Key words: Astrakhan region, insects, long-legged flies, new locality, Protected Area

\section{Introduction}

According to the fauna of the family Dolichopodidae of the Astrakhan region, fragmentary information is available in the literature. In Stackelberg (1933) and Negrobov et al. (2013), two species are mentioned for the Astrakhan region: Dolichopus zernyi Parent, 1927 and Hydrophorus praecox (Lehmann, 1822).

In the article of Grichanov (2011) related to the Astrakhan region, mainly from the vicinity of Lake Baskunchak, two new species (Campsicnemus konstantini Grichanov, 2011, Vetimicrotes baskunchakensis Grichanov, 2011) were described, and the following seven species were indicated for the first time for this region: Campsicnemus magius (Loew, 1845), Chrysotus suavis Loew, 1857, Rhaphium antennatum (Carlier, 1835), Rhaphium micans (Meigen, 1824), Syntormon filiger Verrall, 1912, Syntormon pumilus (Meigen, 1824), Thinophilus flavipalpis (Zetterstedt, 1843). Grichanov (2013) noted Asyndetus longicornis Negrobov, 1973 from the Astrakhan region. Some data on the Dolichopodidae fauna of the Astrakhan State Nature Biosphere Reserve were published in conference proceedings (Lopyreva et al., 2014; Selivanova, 2016).
This study was aimed to review and generalise the whole material on Dolichopodidae fauna in the Astrakhan State Nature Biosphere Reserve (Russia).

\section{Material and Methods}

Material was collected by students of the Voronezh State University during field practice in the Astrakhan State Nature Biosphere Reserve (Fig. 1), using yellow pan traps. For this purpose, water was poured into the yellow pan traps with detergent. Then the captured specimens were transferred into $70 \%$ alcohol. In total, 1490 specimens were collected by G.B. Lopyreva and M.Yu. Anokhin in 2014, and by S.A. Bykovsky in 2017.

The vegetation cover consists of hygrophytes and hydrophytes. At this site, hygrophytes are represented by communities of Phragmites australis (Cav.) Trin. ex Steud. and Typha angustifolia L. (Fig. 2). The group of hydrophytes includes Nelumbo nucifera Gaertn., Sparganium erectum L. s.1., Butomus umbellatus L., Sagittaria sagittifolia L., and Alisma gramineum Lej. (Fig. 3). 

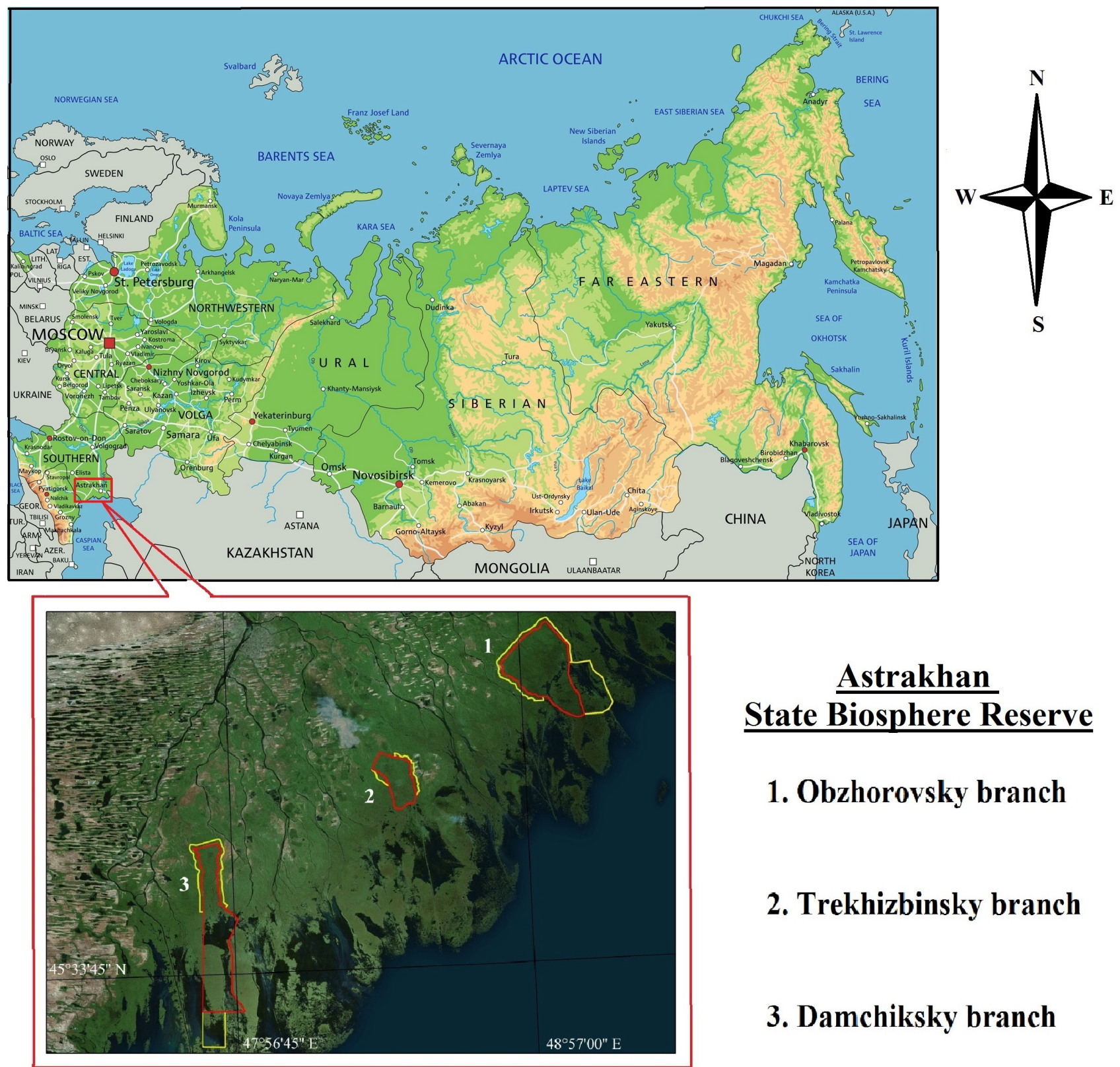

Astrakhan

State Biosphere Reserve

1. Obzhorovsky branch

2. Trekhizbinsky branch

3. Damchiksky branch

Fig. 1. Scheme of the location of the Astrakhan State Nature Biosphere Reserve. Clusters (red line) and their buffer zones (yellow line).

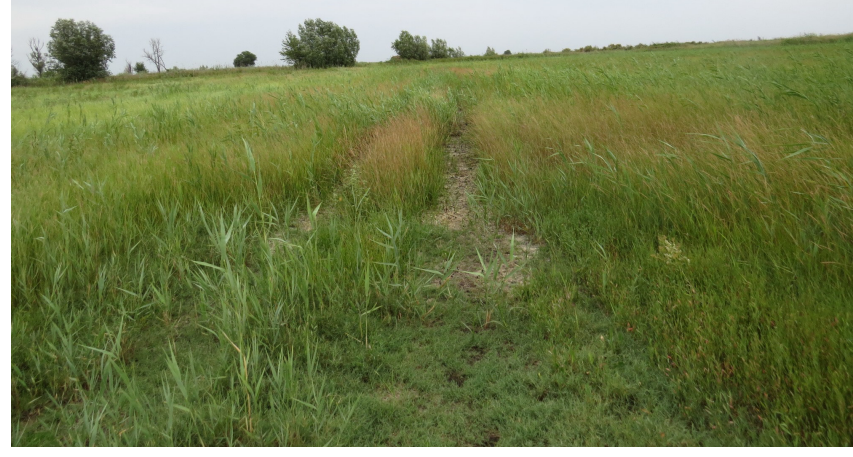

Fig. 2. Habitat of Asyndetus albipalpus and Asyndetus chaetifemoratus, Astrakhan State Nature Biosphere Reserve, Trekhizbinsky branch, Trekhizbinka.

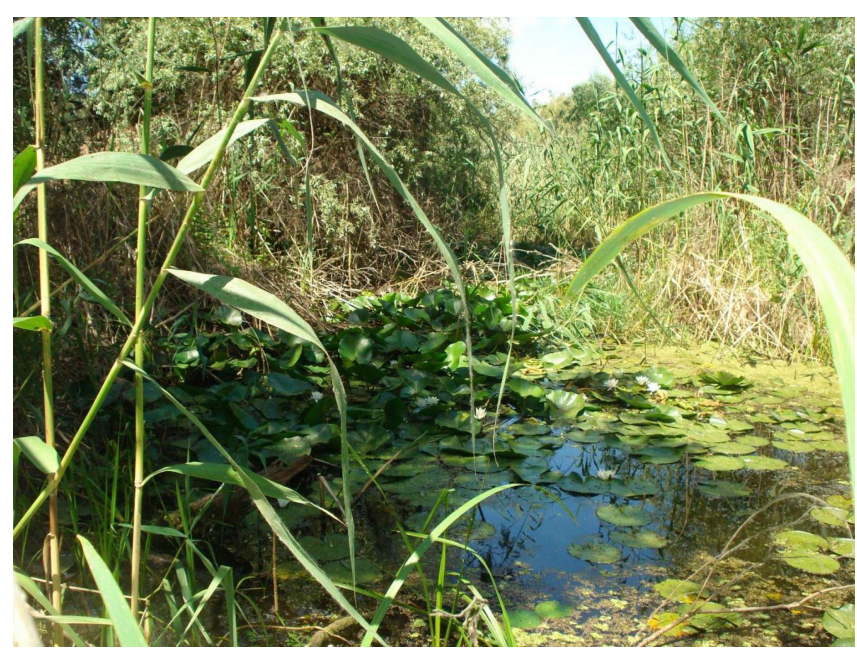

Fig. 3. Habitat of the Dolichopus species. Astrakhan State Nature Biosphere Reserve, Damchiksky branch, Bystraya channel. 


\section{Results and Discussion}

A list of species of the Dolichopodidae family known in the Astrakhan State Nature Biosphere Reserve is presented below. It includes a description of the material (collected specimens), current distribution and some special comments, where needed.

\section{Asyndetus albipalpus Loew, 1871}

Material. $250 \stackrel{\partial}{\partial}, 210$ q, Trekhizbinsky branch, Trekhizbinka, 6-20.07.2017 (Bykovsky); 78 ふै, 56 q, Obzhorovsky branch, 13-20.07.2017 (Bykovsky); 4 J, Damchiksky branch, the bank of the River Bystraya, 24.06.2104 (Lopyreva, Anokhin). It is known from Uzbekistan and Tajikistan. This is the first record for Europe and Russia.

\section{Asyndetus chaetifemoratus Parent, 1925}

Material. 38 ภ, 20 ㅇ, Damchiksky branch, bank of the River Bystraya, 24-25.06.2014 (Lopyreva, Anokhin); 8 $\curvearrowright, 13$ q, Trekhizbinsky branch, Trekhizbinka, 6-20.07.2017 (Bykovsky). The species was described from Egypt. It is also known from Israel and Iraq. It is the first record for Europe and Russia.

\section{Asyndetus latifrons (Loew, 1857)}

Material. $2 \hat{\mathrm{O}}, 1$, , Trekhizbinsky branch, Trekhizbinka, 06.07.2017 (Bykovsky). It is the first record for the Astrakhan region.

Campsicnemus filipes Loew, 1859 (Fig. 4)

Material. $1 \hat{\jmath}, 1+$, Damchiksky branch, bank of the River Bystraya, Obzhorovsky branch 16.06.2014 (Lopyreva, Anokhin). This is a rare species, known from South-West Europe, Morocco, and southern Ukraine. In Russia it was discovered in the Rostov region and Voronezh region. This is the first record for the Astrakhan region.

Campsicnemus simplicissimus Strobl, 1906

Material. 1 o, Obzhorovsky branch, shore of the channel Poldnevoe, 16.06.2014 (Lopyreva, Anokhin). It is known from Central and Southern Europe, Tajikistan and Turkey, in Russia: from KarachaiCherkessia, Krasnodar region, Rostov region. This is the first record for the Astrakhan region.

Chrysotus cilipes Meigen, 1824

Material. 5 N , Damchiksky branch, banks of the River Bystraya, 06.26.2014 (Lopyreva, Anokhin). This is the first record for the Astrakhan region.

\section{Chrysotus dorli Negrobov, 1980}

Material. 8 ô, 8 क, Damchiksky branch, Damchik settlement, 25-30.06.2014, shore of the channel Srednyaya Bystraya, 02-03.07.2014, Obzhorovsky branch, shore of the channel Poldnevoe, 10-15.07.2014 (Lopyreva, Anokhin). The species is described from Tajikistan. Currently, it is also known from Turkey. This is the first record for Europe and Russia.

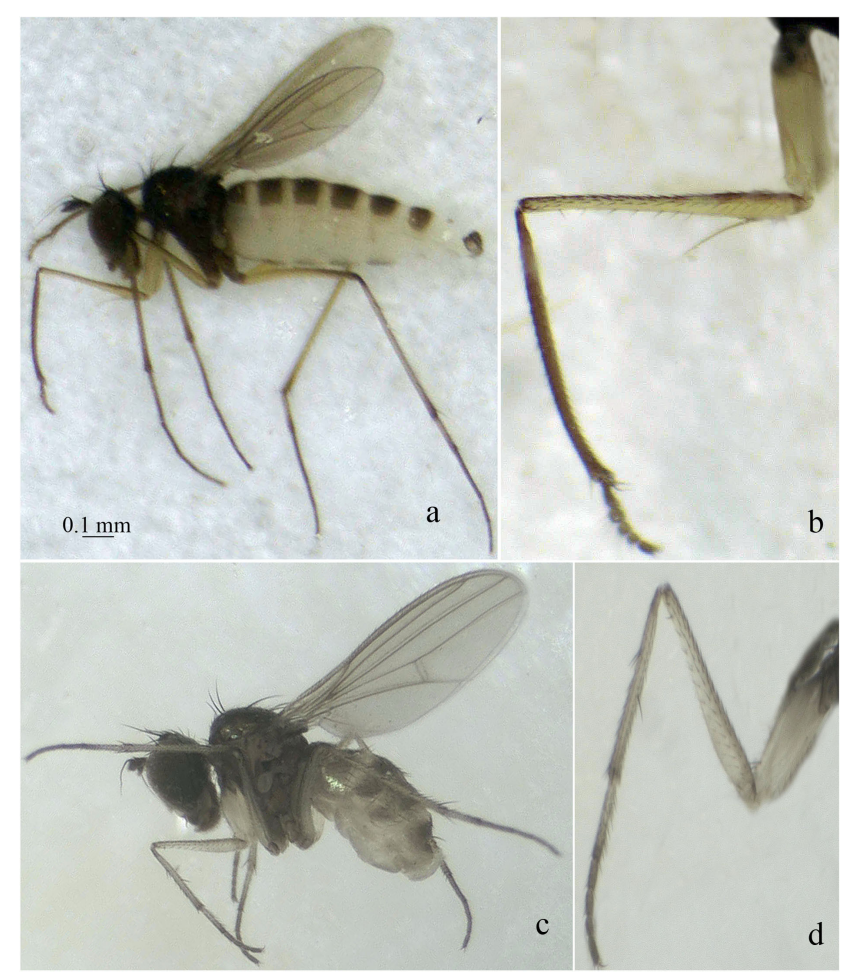

Fig. 4. Campsicnemus filipes: a - habitus, male, lateral view; $\mathrm{b}$ - male, fore legs; $\mathrm{c}$ - habitus, female; $\mathrm{d}$ - female, fore legs.

\section{Dolichopus austriacus Parent, 1927}

Material. $60 \hat{\jmath}, 52$, , Damchiksky branch, Damchik settlement and Obzhorovsky branch, the shores of the channel Poldnevoe, 3-16.07.2014 (Lopyreva, Anokhin).

\section{Dolichopus calinotus Loew, 1871}

Material. $1 \hat{\jmath}, 4$ \& Astrakhan Region, Astrakhan State Biosphere Reserve, Damchiksky branch, bank of the river, Bystraya stream, 2529.06.2014 (Lopyreva, Anokhin); 98 ô, 114 q, Obzhorovsky branch, river bank, Obzhorovo channel, 10-16.07.2014 (Lopyreva, Anokhin); 8 त, 2 , , Obzhorovsky branch, river bank, the Poldnevoe channel, 15.07.2014 (Lopyreva, Anokhin). This is a rare species, known from southwestern Europe. In Russia it was discovered only in the North Caucasus (Grichanov et al., 2006). This is the first record for the Astrakhan region.

The species Dolichopus sabinus Haliday, 1838 was noted by Lopyreva et al. (2014). It should be referred to the species Dolichopus calinotus. The latter differs from Dolichopus sabinus on the base of the hypopygium structure (Fig. 5).

\section{Dolichopus cilifemoratus Macquart, 1827}

Material. 125 ภ, 109 ㅇ, Damchiksky branch, Damchik settlement, 28.29.06.2014; Obzhorovsky branch, shore of the channel Poldnevoe, 10-16.06.2014 (Lopyreva, Anokhin). It is known from Western Europe, European Russia and Siberia. This is the first record for the Astrakhan region. 


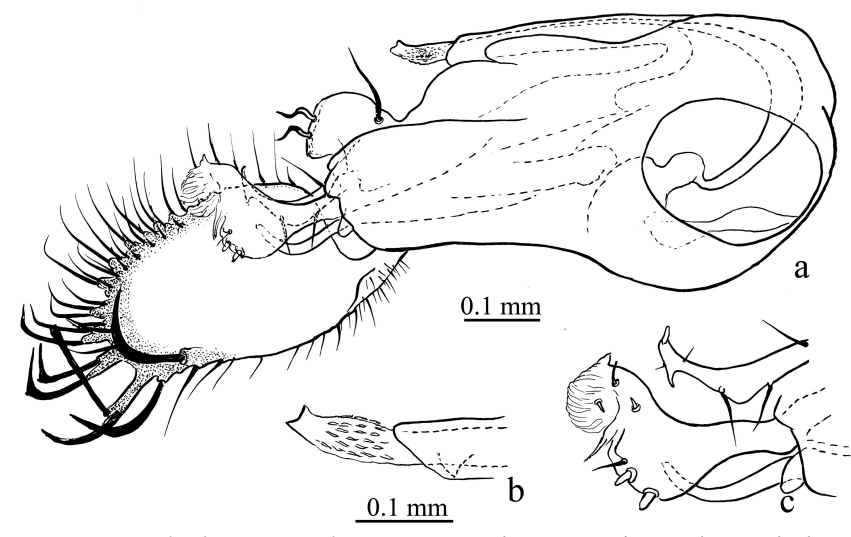

Fig. 5. Dolichopus calinotus: a - hypopygium, lateral, b apical part of phallus, $\mathrm{c}$ - surstylus, lateral.

\section{Dolichopus latilimbatus Macnuart, 1827}

Material. $2 \hat{\jmath}$, Obzhorovsky branch, shore of the channel Poldnevoe, 11.07.2014 (Lopyreva, Anokhin). It is known from Western Europe and European Russia. This is the first record for the Astrakhan region.

\section{Dolichopus jaxarticus Stackelberg, 1927}

Material. 28 ô, 34 क, Damchiksky branch, Damchik settlement, 24-30.06, 03-07.07.2014; Obzhorov area, the shore of the Obzhorov channel, 10-16.07.2014 (Lopyreva, Anokhin). It is known from Central Asia, China and Ukraine. This is the first record for Russia.

\section{Dolichopus zernyi Parent, 1927}

Material. 83 ô, 153 , Damchiksky branch, Damchik settlement, 24.06-02.07.2014 (Lopyreva, Anokhin). It was described from Sarepta (former Krasnoarmeysk, near Volgograd). The species is known from the south and middle belts of the Palaearctic, from Kazakhstan, China and Russia (Astrakhan region, Volgograd region, Voronezh region).

\section{Hercostomus convergens (Loew, 1857)}

Material. 6 O, 7 , , Obzhorovsky branch, shore of the channel Poldnevoe, 10-16.07.2014 (Lopyreva, Anokhin). It is distributed in Central and Southern Europe, Western Asia. In Russia, it is known from Krasnodarsky Krai and Voronezh region. This is the first record for the Astrakhan region.

Hercostomus rubroviridissimus Negrobov, 1977

Material. 1 on, 2 + , Damchiksky branch, $2^{\text {nd }}$ cordon, 1-2.07.2014 (Lopyreva, Anokhin). I is known from Uzbekistan and Mongolia. This is the first record for Europe and Russia.

\section{Medetera diadema (Linnaeus, 1767)}

Material. 6 o, 8 क , Damchiksky branch, the banks of the middle River Bystraya, 24.06.2014, 03-06.07.2014 (Lopyreva, Anokhin). This is the first record for the Astrakhan region.

\section{Medetera plumbella Meigen, 1824}

Material. $1 \hat{\sigma}$, Trekhizbinsky branch, Trekhizbinka, 06.07.2017 (Bykovsky). This is the first record for the Astrakhan region.

\section{Nematoproctus longifilus Loew, 1857}

Material. $9 \curvearrowright, 11$ + , Damchiksky branch, village Damchik, bank of the Bystraya river, 02.07.2014, Obzhorovsky branch, shores of the channel Poldnevoe, 15.07.2014 (Lopyreva, Anokhin). It is known from Western Europe and Russia (only in the Voronezh region). This is the first record for the Astrakhan region.

\section{Poecilobothrus bigoti Mik, 1883}

Material. 8 ô, 1 क, Damchiksky branch, 02.07.2014, Obzhorovsky branch, shores of the channel Poldnevoe, 15-16.07.2014 (Lopyreva, Anokhin). It is known from Western Europe and Russia (only in the North Caucasus). This is the first record for the Astrakhan region.

\section{Rhaphium antennatum (Carlier, 1835)}

Material. 6 ก, 2 \&, Damchiksky branch, village Damchik, 29-30.06.2014 (Lopyreva, Anokhin). It is known from Central and Southern Europe, Iran and Russia - in the Moscow region, Voronezh region, and the North Caucasus.

\section{Rhaphium penicillatum Loew, 1850}

Material. $1 \hat{\partial}$, Obzhorovsky branch, shore of the channel Poldnevoe, 11.07.2014 (Lopyreva, Anokhin). It is known from Iran, Europe and Russia - from the Leningrad region, Voronezh region, Krasnoyarsky Krai, in the North Caucasus. This is the first record for the Astrakhan region.

\section{Sciapus longulus (Fallen, 1823)}

Material. 57 ๙ึ, 26 ㅇ, Damchiksky branch, bank of the River Bystraya, 24-25.06.2014, Obzhorovsky branch, shores of the channel Poldnevoe, 10-15.07.2014 (Lopyreva, Anokhin). This is the first record for the Astrakhan region.

Sciapus subvicinus Grichanov, 2007

Material. $2 \hat{\sigma}, 11$ q, Damchiksky branch, bank of the River Bystraya, 02.07.2014; Obzhorovsky branch, shore of the channel Poldnevoe, 1516.07.2014 (Lopyreva, Anokhin). It is described from the south of Ukraine, listed for the fauna of Armenia, Kazakhstan and Uzbekistan. This is the first record for Russia.

This work provides data on four species new for both Europe and Russia: Asyndetus albipalpus, Asyndetus chaetifemoratus, Chrysotus dorli, and Hercostomus rubroviridissimus. In addition, Sciapus subvicinus and Dolichopus jaxarticus are new species for Russia. 
Thus, 23 species from the Dolichopodidae family were found in the Astrakhan State Nature Biosphere Reserve. Twenty of these species are recorded for the first time for the Astrakhan region. In total, to date 34 species from the family Dolichopodidae are known from the Astrakhan region taking into account previously known species.

The studies of Dolichopodidae species of Protected Areas are extremely inadequate, being represented by separate regional faunistic lists. The most complete species list of this taxonomic group is published for the Caucasus State Natural Biosphere Reserve, which contains 151 species, including 25 endemics for the Caucasus and the endemic genus Guzeriplia Negrobov, 1968 (Negrobov, 1967, 1968, Negrobov \& Shamshev, 1984; Negrobov \& Selivanova, 2005; Grichanov et al., 2006).

The first record of the genus Nepalomyia Hollis for the Western Palearctic has been revealed from the Teberda State Nature Biosphere Reserve (Negrobov et al., 2018).

From the Prioksko-Terrasny Nature Biosphere Reserve, 20 species of the Dolichopodidae family are known (Tamarina et al., 1984). There are five species in the territory of Wrangel Island Nature Reserve (Grichanov \& Khruleva, 2018). Twenty species are indicated for the Tigirekskii State Nature Reserve (Grichanov, 2017). Twenty nine species are known from the Utrish State Nature Reserve (Kustov et al., 2016). Finally, 25 species are noted from the West Kotlin State Nature Reserve (Grichanov \& Ovsyannikova, 2017).

In addition, a number of species lists and new species descriptions was published from the following Protected Areas: Voronezh State Nature Biosphere Reserve, Central Chernozem State Nature Biosphere Reserve, Khopersky State Nature Reserve, State Nature Reserve "Galichya Gora», State Nature Reserve «Stolby», Lapland State Nature Biosphere Reserve, Kandalaksha State Nature Reserve, Barguzinsky State Nature Biosphere Reserve, State Nature Reserve «Kedrovaya Pad» (see: Negrobov et al., 2013).

Thus, there are numerous and scattered data on the Dolichopodidae family from many regions of Russia. Therefore, further studies, including field inventories, critical reviews, are needed for revealing data on distribution, ecology, taxonomy of the Dolichopodidae family in Russia and Eurasia as a whole.

\section{Acknowledgments}

The authors are grateful to Kirill V. Litvinov (Deputy Director for Science of the Astrakhan State Nature Bio- sphere Reserve, Russia) for help and advice, and to the officers of the Astrakhan Reserve for providing the Protected Area scheme and description of the vegetation in the studied habitats of the collected species. The authors are grateful to Igor Ya. Grichanov (All-Russian Institute of Plant Protection, Russia) for comments on the manuscript.

\section{References}

Grichanov I.Ya. 2011. New species and new records of Dolichopodidae (Diptera) from Astrakhan Region of Russia. Russian Entomological Journal 20(1): 75-80.

Grichanov I.Ya. 2013. Afrotropical species of the genus Asyndetus Loew (Diptera: Dolichopodidae) with notes on some Palaearctic and Oriental species. In: I.Ya. Grichanov, O.P. Negrobov (Eds.): Fauna and taxonomy of Dolichopodidae (Diptera). St. Petersburg: VIZR. P. 27-46.

Grichanov I.Ya. 2017. First data on Dolichopodidae (Diptera) of the Tigirekskii Nature Reserve (Altai Territory, Russia). Acta Biologica Sibirica 3(1): 34-39. DOI: 10.14258/abs.v3i1.2181

Grichanov I.Ya, Ovsyannikova E.I. 2017. First data on Dolichopodidae (Diptera) of the West Kotlin Nature Reserve (Saint Petersburg, Russia). Acta Biologica Sibirica 2(4): 11-14. DOI: 10.14258/abs.v3i2.2732

Grichanov I.Ya., Khruleva O.A. 2018. Fauna and ecology of Dolichopodidae (Diptera) from Wrangel Island Nature Reserve (Chukotka, Russia). Nature Conservation Research 3(3): 37-45. DOI: 10.24189/ncr.2018.023

Grichanov I.Ya., Kustov S.Yu., Volfov B.I. 2006. A checklist of Dolichopodidae (Diptera) of Krasnodar Territory and Adygea (Russia). Dipterological Research 17(1): 35-55.

Kustov S.Yu., Grichanov I.Ya. Getman A.A. 2016. The Empidoidea (Diptera) of the Utrish Nature Reserve, Russia. Halteres 7: 46-63.

Lopyreva G.B., Anokhin M.Yu., Selivapova O.V. 2014. Some data on the fauna of the family Dolichopodidae (Diptera) Astrakhan reserve. In: Proceedings of Conference "Modern problems of specially protected natural areas of regional importance and ways of their solution» (18.12.2014, Voronezh). Voronezh: Voronezh State University. P. 134-137. [In Russian]

Negrobov O.P. 1967. Fauna and vertical distribution of the Dolichopodidae (Diptera) of the Western Caucasus. Zoologicheskii Zhurnal 48(7): 1074-1080. [In Russian]

Negrobov O.P. 1968. New genus and species of Dolichopodidae (Diptera). Zoologicheskii Zhurnal 47(3): 470-473. [In Russian]

Negrobov O.P, Shamshev I.V. 1984. New data on the fauna of the Dolichopodidae (Diptera) of the Caucasus. Vestnik Zoologii 6: 49-51. [In Russian]

Negrobov O.P., Selivanova O.V. 2005. A new species of the genus Argyra (Diptera, Dolichopodidae) from the North Caucasus. Bulletin of Moscow Society of Naturalists. Biological series 110(3): 70-71. [In Russian]

Negrobov O.P., Chursina M.A., Selivanova O.V., Maslova O.O. 2013. Check-list of predatory flies of the family Dolichopodidae (Diptera) in the fauna of Russia. In: I.Ya. Grichanov, O.P. Negrobov (Eds.): Fauna and 
taxonomy of Dolichopodidae (Diptera). St. Petersburg: VIZR. P. 47-93.

Negrobov O.P, Selivanova O.V, Maslova O.O. 2018. The First Record of the Genus Nepalomyia Hollis (Diptera, Dolichopodidae) for the Western Part of the Palaearctic Region. Entomological Review 98(2): 213-217. DOI: 10.1134/S0013873818020124

Selivanova O.V. 2016. Rare and little-known species of the family Dolichopodidae (Diptera) of the Astrakhan Re- serve. In: X All-Russian Dipterological Symposium (2328 August, 2016). Krasnodar. P. 294-298. [In Russian] Stackelberg A.A. 1933. 29. Dolichopodidae. In E. Lindner (Ed.): Die Fliegen der Palaearktischen Region 4(5), Lief. 71. P. 65-128.

Tamarina N.A., Smirnov E.S., Negrobov O.P. 1984. Towards the Diptera fauna of family Dolichopodidae (Diptera) in the Prioksko-Terrasny Reserve (Moscow Region). Entomological Review 63(4): 716-721. [In Russian]

\title{
ФАУНА СЕМЕЙСТВА DOLICHOPODIDAE (DIPTERA) АСТРАХАНСКОГО ГОСУДАРСТВЕННОГО ПРИРОДНОГО БИОСФЕРНОГО ЗАПОВЕДНИКА (РОССИЯ)
}

\author{
О. П. Негробов ${ }^{1}$ О. О. Маслова ${ }^{2}$, О. В. Селиванова ${ }^{1}$ \\ ${ }^{1}$ Воронежский государственный университет, Россия \\ e-mail:negrobov@list.ru \\ ${ }^{2}$ Воронежский государственный педагогический университет, Россия \\ e-mail:oom777@yandex.ru
}

В работе представлен критический обзор семейства Dolichopodidae Астраханского государственного природного биосферного заповедника (Россия). Для Астраханского заповедника указано 23 вида семейства Dolichopodidae. Впервые для Европы и России приводится четыре вида Asyndetus albipalpus, Asyndetus chaetifemoratus, Chrysotus dorli, Hercostomus rubroviridissimus. Sciapus subvicinus и Dolichopus jaxarticus впервые отмечены для России. Впервые для Астраханской области указано 20 видов: Asyndetus albipalpus, Asyndetus chaetifemoratus, Asyndetus latifrons, Campsicnemus filipes, Campsicnemus simplicissimus, Chrysotus cilipes, Chrysotus dorli, Dolichopus cilifemoratus, Dolichopus latilimbatus, Dolichopus jaxarticus, Hercostomus convergens, Hercostomus rubroviridissimus, Medetera diadema, Medetera plumbella, Nematoproctus longifilus, Poecilobothrus bigoti, Rhaphium penicillatum, Sciapus longulus, Sciapus subvicinus. С учетом литературных данных к настоящему времени для Астраханской области известно 34 вида из семейства Dolichopodidae. Тем не менее необходимы дальнейшие исследования фауны семейства Dolichopodidae на особо охраняемых природных территориях для получения более полных сведений об этом семействе двукрылых в России и в Евразии в целом.

Ключевые слова: Астраханская область, мухи-зеленушки, насекомые, новое местонахождение, особо охраняемая природная территория 